УДК 94(477) «1996/2016»:355.3.1:614.39

КАЗАН Е. М.

https://orcid.org/0000-0002-0997-6945

ГОЛЯЧУК І. П.

https://orcid.org/0000-0002-3817-3180

https://doi.org/10.33577/2313-5603.33.2020.87-98

\title{
СТАНОВЛЕННЯ І РОЗВИТОК ВІЙСЬКОВО-МЕДИЧНОЇ СЛУЖБИ ЧЕРВОНОЇ АРМІЇ У ДРУГІЙ СВІТОВІЙ ВІЙНІ
}

У статті відображено вплив Другої світової війни на процес формування військово-медичної служби Червоної Армії СРСР, частиною якого була в той період Україна. Показано, як видозмінювалось медичне забезпечення в різних періодах війни, як розвивалась військово-медична освіта і наука, змінювались підходи до надання медичної допомоги в бойових умовах та удосконалювалась система лікувально-евакуаційного забезпечення, формувалась матеріально-технічна база, розвивались санітарний транспорт та авіація. Доведено, що Друга світова війна дала могутній поштовх для розвитку військової медицини, іiі науки, техніки та освіти.

Ключові слова: санітарна служба, Друга світова війна, Робітничо-Селянська Червона Армія (РСЧА)

Актуальність теми. Розпад Радянського Союзу, відновлення незалежності України докорінно трансформували військово-політичні пріоритети нашої держави. Одним із них було утворення власних Збройних сил, а, відповідно, і всіх видів їх забезпечення, в тому числі медичного. Дислоковані в той період на території України військові медичні формування колишньої Червоної Армії були реформовані в військово-медичну службу Збройних Сил України, та їх напрацьовані десятиліттями здобутки і досягнення були використані в процесі становлення нової організаційної військово-медичної структури та військової медицини загалом. Тому потужний бойовий досвід Другої світової війни вплинув на розвиток військово-медичної служби ЗС України у всіх аспектах i в плані виховання медичних та командно-медичних кадрів та появи і розвитку мережі військово-медичних закладів освіти, і на розвиток воєнної науки та думки, зокрема військово-польової хірургії та терапії, і на становлення всієї системи медичного забезпечення.

Казан Емілія Мар'янівна, кандидат історичних наук, викладач кафедри тактики Національної академії сухопутних військ імені гетьмана Петра Сагайдачного, м. Львів

Голячук Ігор Петрович, старший викладач кафедри тактики Національної академії сухопутних військ імені гетьмана Петра Сагайдачного, м. Львів

(C) Казан Е.M., Голянчук І.П., 2020 
Саме в роки Другої світової війни сформувалась прогресивна система лікувально-евакуаційного забезпечення поранених і хворих 3 евакуацією за призначенням. Саме Друга світова війна дала поштовх до розвитку матеріально-технічного забезпечення військовомедичної служби, розвитку санітарного автомобільного транспорту та санітарної авіації. Тому досвід Другої світової війни для медичної служби є актуальним для нашого сьогодення.

Meта статmi - проаналізувати досвід Другої світової війни для військово-медичної служби і дослідити його вплив на іiі подальший розвиток.

Виклад основного матеріалу. Радянська військова медицина бере свій початок від моменту створення Робітничо-Селянської Червоної Армії (РСЧА) декретом, ухваленим у січні 1918 р. За довоєнний період сформувалася військово-медична служба СРСР. Ïї центральні і місцеві органи управління очолили військові лікарі, які вперше об'єднали лікарську та адміністративно-організаційну посадові функції. У цей час зародилися перші організаційні принципи медичного забезпечення Червоної Армії, які спиралися на досвід Першої світової війни, впроваджувалися принципи поетапного лікування. По закінченні громадянської війни принципи медичного забезпечення здобули свій подальший розвиток у документі "Керівництво по санітарній евакуації в РСЧА" (1929р.). Це був перший в СРСР документ статутного характеру 3 питань медичного забезпечення, де обгрунтовувалось сортування поранених і хворих та їх поетапне лікування. Система лікувальноевакуаційного забезпечення представляла собою ланцюг етапів медичної евакуації, і всі поранені і хворі мали послідовно проходити через всі ланки цього ланцюга. Евакуацію мав здійснювати кінно-санітарний транспорт.

Наприкінці 1933 р. «Керівництво» було замінене «Статутом військово-санітарної служби РСЧА», який відрізнявся від «Керівництва» важливим фактором - в ньому принцип поетапного лікування видозмінювався евакуацією згідно з бойовою патологією. Транспортування поранених вже не відбувалося механічно, з етапу на етап, здійснювалася евакуація пораненого на той етап евакуації, де йому буде надана кваліфікована медична допомога згідно 3 його медичними показаннями (Статут ВСС РСЧА, 1933: 7). Передбачалося змінити кінний санітарний транспорт на санітарні 
автомобілі та санітарні літаки. Вирішення цих завдань було пропорційним до наявності в військово-медичній службі швидкохідних транспортних засобів - автомобільних і авіаційних. Але до 1935 р. масовий випуск санітарних автомобілів в СРСР не здійснювався. Тому станом на 1 травня 1935 р. забезпеченість Червоної Армії автосанітарним транспортом складало тільки 6,6\% від потреби. У 1936 р. для потреб Червоної Армії державне замовлення становило 600 машин. У 1938 р. автосанітарний транспорт (три автомобілі) був введений в штат медичної служби полку. Але до кінця 1938 р. потреби медичної служби в автотранспорті були задоволені тільки на 10\% (Кувиинский, 1968: 159).

У цьому ж 1938 р. відбулися зміни в польовій військовомедичній організації Червоної Армії: в батальйоні був створений штатний санітарний взвод на чолі з лікарем. Це зробили задля наближення першої лікарської допомоги до лінії фронту. Ця ідея була підказана досвідом війни в Іспанії, коли в інтернаціональних бригадах республіканських військ батальйонний лікар відігравав основну роль нарівні 3 хірургом. Першим випробуванням для радянської військово-медичної служби та системи медичного забезпечення стали бої на озері Хасан, на річці Халхін-Гол та в період радянсько-фінської війни. На організацію медичного забезпечення на озері Хасан та річці Халхін-Гол впливали місцеві умови. У військовій ланці медичної служби найбільш повно проявилась невідповідність регламентованих документами того часу вимог виносити поранених з поля бою за сприятливих умов (вночі або в міжбойових паузах). В даному випадку поранених виносили безперервно під час бою. Керували виносом і організовували надання першої допомоги батальйонні лікарі, або самі ж вони і надавали цю допомогу. Це було зумовлено тим, що батальйонні пункти медичної допомоги не могли бути розгорнуті через небезпеку прямого обстрілу з боку японців. Тому лікарі батальйонів не могли виконувати свої передбачені Статутом обов'язки. Таке нецільове використання лікарського складу спричинило рішення керівників військово-медичної служби замінити цих лікарів на фельдшерів, а самих лікарів перевести в полки. Подібні проблеми спіткали військових медиків і в радянсько-фінську війну. Там, як і в Хасанській та Халхінгольській операції, винесення поранених відбувалося неперервно, під час боїв, безпосередньо на батальйонні пункти медичної допомоги. Характерною протягом 
всіх бойових дій була нестача санітарів, санітарних інструкторів та стрільців-санітарів, серед яких були великі незворотні втрати.

Батальйонні пункти медичної допомоги розташовувались за 200 або 2000 м від лінії фронту в бліндажах чи палатках. На них надавалась в основному долікарська допомога, бо лікарі батальйонів не мали можливостей для виконання своїх лікарських обов'язків. 3 батальйонних пунктів поранені на волокушах, собачих упряжках чи лижно-носильних установках евакуйовувались на полковий пункт медичної допомоги, де число прибулих поранених в дні жорстоких боїв досягало 200 - 400 осіб. Тоді обсяг медичної допомоги різко зменшувався до накладення джгута, контролю накладеної пов'язки, накладення шин тощо. 3 полкових пунктів всі поранені евакуйовувались на дивізійні пункти медичної допомоги, де було прооперовано близько $65 \%$ поранених.

Період між радянсько-фінською та радянсько-німецькою війнами був короткий, і врахувати недоліки та скористатись набутим досвідом військово-медична служба СРСР не зуміла. Тільки в червні 1941 р. з'явився проект «Настанов з санітарної служби Червоної Армії», де були викладені питання медичного забезпечення, напрацьовані на підставі досвіду радянсько-фінської війни 1939 - 1940 р. На початку радянсько-німецької війни близько половини гарнізонних шпиталів Прибалтійського, Західного та інших округів терміново евакуювались на Схід, не маючи змоги забрати медичне майно. Частина шпиталів була зруйнована від бомбардувань або була захоплена. В донесенні Військово-санітарного управління Західного фронту від 30 червня 1941 р., скерованому до начальника Санітарного управління Червоної Армії було написано, що всі санітарні заклади, дислоковані на території західної і частково східної Білорусі, не відмобілізувались, i фронт позбувся 32 хірургічних і 12 інфекційних шпиталів, 3 автосанітарних рот, 3 санітарних складів, 3 управлінь госпітальних баз армії, 7 управлінь евакопунктів, евакогоспіталів на 17 тис. ліжок. Станом на 1 липня 1941 р. на Західному та Південно-Західному фронті розгорнули тільки $15 \% 3$ запланованих на початку війни медичних частин. На 1 серпня не вистачало 40\% польових пересувних госпіталів, автохірургічних загонів - 52\%, автосанітарних рот - 48,8\% (Кувиинский, 1968: 199). Значну роль в зниженні ефективності роботи медичної служби відігравала мала кількість автомобільного транспорту. Щоб якось компенсувати цей недолік, 
були створені кінно-санітарні роти, частина польових пересувних госпіталів були сформовані не на автомобільній, а на кінній тязі.

Майно санітарних закладів знищено пожежами та бомбардуваннями. У військах і санітарних закладах бракувало перев'язувального матеріалу, наркотичних засобів та сироваток. Через евакуацію підприємств хіміко-фармацевтичної промисловості та нестачі сировини припинилось виробництво медикаментів і медичного майна. Стан $з$ постачанням діючої армії медичним майном навіть під час перебудови економіки на воєнний лад з листопада 1942 по грудень 1943 р. продовжував залишатися досить напруженим. До того ж вантажі, що відправлялися на фронти, нерідко прибували на місце призначення із запізненням на 2-3 місяці і більше. Вихід знаходили в тому, що здійснювали заготівлю медичного майна на місцях. Так, в 1943 р. на фронтах було заготовлено: медикаментів - 44\%, перев'язувальних засобів - 19,5\%, хірургічних інструментів $12-13 \%$ від загальної необхідної кількості, особливо бракувало гіпсу, кровозамінників, сульфаніламідних засобів.

Слід нагадати, що на початку війни в Червоній Армії були створені служби переливання крові. Цивільні заклади переливання крові (ї було 1500 до війни) з початком війни переводяться на воєнний стан. У блокадному Ленінграді Інститут переливання крові постійно піддавався бомбардуванням, не вистачало флаконів, стерильного матеріалу, води, але Інститут забезпечував фронт кров’ю. В 1943 р. запроваджено пересувні мобільні станції переливання крові для кожного фронту. До кінця 1943 р. створено 10 таких пересувних станцій. Виходячи з досвіду роботи у фронтових умовах, вченими розроблений двоетапний метод заготівлі крові, котрий сьогодні є практичною основою для консервування крові (Історія розвитку застосування крові, 2016).

3 введенням централізованого постачання діючої армії кров'ю та препаратами медична служба Червоної Армії у 1943 р. отримала понад 250 тис. літрів консервованої крові, що дозволило виконати переливання крові 13,4\% від загальної кількості поранених за цей рік. (6, ст. 29). Всього за період Великої Вітчизняної війни в тилу країни донорами стали близько 5,5 млн людей, а діюча армія отримала близько 1,7 млн літрів консервованої крові (Історія розвитку застосування крові, 2016). 
Основну роль в медичному забезпеченні радянських військ на радянсько-німецькому фронті відігравали полкові медичні пункти, медико-санітарні батальйони дивізій, сформовані до війни в прикордонних округах, кадрові польові пересувні і гарнізонні госпіталі. Ці частини і заклади медичної служби були укомплектовані за штатом мирного часу, тобто мали недостатню кількість особового складу, майна і транспорту для діяльності в умовах війни, але змушені були діяти в бойовій обстановці існуючими силами та засобами.

3 листопада 1942 р. до грудня 1943 р. 3 розвитком воєнної економіки з'являються нові лікувальні заклади,зростає ліжковий фонд госпітальних баз армій і фронтів. У грудні 1942 р. замість уніфікованих польових рухомих госпіталів були створені хірургічні на 200 ліжок і терапевтичні на 100 ліжок польові рухомі госпіталі.

Внаслідок проведених організаційних заходів в період 31 січня 1943 р. по 1 січня 1944 р. госпітальна мережа СРСР збільшилася на $23 \%$, кількість окремих дезінфекційних рот зросла з $30 \%$ до $83 \%$. Велика увага приділялась формуванню госпіталів для легкопоранених - для швидкого повернення до лав поранених $\mathrm{i}$ хворих. Кількість ліжок у цих госпіталях склала 1/3 від їх загальної кількості в діючій армії (Організачія медичного забезпечення військ, 2005: 29).

Для початку війни характерною була нестача медичних кадрів. На Західному фронті нестача лікарів на липень 1941 р. становила $50 \%$. На війни Червона армія була укомплектована фельдшерами на 63,7\%. Штат санітарів та санітарних інструкторів був нечисельним, а призвані на ці посади особи були погано навчені. Через це, крім призову на військову службу з запасу, відбулись дострокові випуски військово-медичних академій, цивільних медичних вузів. Потім вищі медичні учбові заклади перейшли на 4-річне навчання, без видачі лікарських дипломів. В жовтні 1941 р. були організовані 5 шкіл молодших військових фельдшерів 3 7-місячним курсом навчання. В округах створювали школи санінструкторів і курси перепідготовки лікарів запасу. Всі ці заходи сприяли укомплектуванню медичної служби кадрами. В результаті через рік війни в Червоній Армії було лікарів - 91\%, фельдшерів $97,9 \%$, санінструкторів - 91,8\%. Але бракувало хірургів - 50\%, токсикологів - 57,7\% (Кувшинский, 1968: 206). 
3 кінця 1942 р. у зв’язку з розвитком військової освіти та в ході мобілізацій забезпеченість медичної служби особовим складом зросла. Так, станом на 1 травня 1943 р. укомплектованість лікарями досягла 92\%, а фельдшерами - 92,9\%. На січень 1943 р. забезпеченість фронтів старшими операційними медсестрами була 94,5 - 100\%, а санітарними інструкторами 70,1\% - 99,1\%. До травня 1943 р. зросла укомплектованість хірургами на 13,8\%, але все одно їх некомплект був ще великий - 36,2\%. (Кувщинский, 1968: 243). Надалі бракувало в медичній службі санітарів та санітарів-стрільців. Їх укомплектованість на фронтах коливалась від 58 до 72\%. Це було зумовлено і використанням їх в якості рядових бійців в бойових порядках військ. 3 січня 1944 р. зростає укомплектованість медичної служби лікарським складом. Загальна кількість фельдшерів досягла на травень 1944 р. до 99,3\%. У липні 1944 р. вона склала 94,5\%. Це зростання здійснювалося за рахунок випускників медичних та військово-медичних навчальних закладів країни. Але забезпеченість хірургами надалі була недостатньою, всього 68\%. А от загальна кількість фельдшерів станом на травень 1944 р. досягла 99,3\%.

В забезпеченні армії і фронту висококваліфікованими лікарськими кадрами вирішальну роль грала військово-медична академія ім. С.М. Кірова, яка щорічно випускала близько 200 лікарів. Така кількість була недостатня для збройних сил, тому було прийнято рішення переводити на 3-й та 4-й курс цієї Академії студентів із цивільних вищих медичних закладів (Наказ РЗС СРСР, 1929). А навесні 1939 р. було відкрито ще 5 вищих військових навчальних закладів, які готували військових лікарів. Серед них Куйбишевська військово-медична академія, військові факультети при медичних інститутах. Щодо середнього військовомедичного персоналу, то 3 листопада 1925 р. при Військовомедичній академії була заснована школа старших лікарських помічників. Потім назву змінили на Школу військово-лікарських помічників, потім на Військово-медичну школу РСЧА, а з 1936 р. на Ленінградське військово-медичне училище. У грудні 1935 р. воно стало самостійним навчальним закладом з підпорядкуванням військово-санітарному управлінню РСЧА. Відповідні військовомедичні училища 3 підготовки фельдшерів для флоту відкрилися в Харкові - в 1935 р., Києві - у 1939 р., Кронштадті - у 1938 р. Важливе місце займали в системі перепідготовки військоволікарських кадрів окружні курси вдосконалення медичного складу. 
В 1928 р. відбувся перший навчальний збір вищого медичного складу з проведенням польових занять. Це були перші в історії медичної служби Червоної Армії заняття такого типу. Такі окружні військові збори стали проводитись регулярно з 1929 р. (Военносанитарное дело, 1929).

Підготовка санітарних інструкторів (до 1929 р. молодші лікарські помічники) протягом багатьох років велася в окружних госпіталях. В 1931 році відкриті окружні і флотські школи санітарних інструкторів, які до 1936 р. функціонували при окружних госпіталях, а потім були підпорядковані безпосередньо військовосанітарним відділам округів (Кувшинский, 1968: 167).

У 1943 р. звертається увага на підвищення рівня підготовки медичних кадрів: відновлюється повноцінний термін навчання у медичних закладах, скорочений в 1941 р., зокрема в лютому 1943 р. були ліквідовані школи молодших військових фельдшерів зі скороченим 7-місячним терміном навчання. 23 листопада 1943 р. прийнятий проект постанови про реорганізацію Військово-медичної академії. У ході наступальних операцій осінньо-зимової кампанії другого періоду війни чітко виявилися недоліки у підготовці керівної ланки медичної служби. Тому було вирішено створити три факультети: командно-медичний, лікувально-профілактичний та факультет підготовки старших лікарів полків (Організація медичного забезпечення військ, 2005: 29).

Друга світова війна внесла зміни i в розвиток військовомедичної науки. В цей час в плані надання медичної допомоги давалась взнаки відсутність єдиного розуміння принципів медичного забезпечення та надання медичної допомоги. Це було пов'язане $з$ тим, що призвані цивільні лікарі та випускники цивільних медичних вузів були незнайомі з документами, які регламентують методи лікувальної роботи в воєнний час. Тому в початковий період війни багато лікарів застосовували різну тактику лікування, що залежало від наукової школи, до якої належав лікар, його досвіду роботи в польових умовах.

Досвід Другої світової війни відкрив багато цінного для воєннопольової хірургії. Вирішилась проблема первинної хірургічної обробки вогнепальної рани з забороною накладення на неї шва відразу після обробки, що є небезпечним для життя пораненого, оскільки не було бактеріостатичних засобів, які змогли б затримати розмноження мікробів після первинної хірургічної обробки рани. 
Заборона накладення первинного шва після первинної хірургічної обробки вогнепальної рани була прийнята під час радянськофінської війни всіма хірургами Червоної Армії. Досвід хірургічної роботи був викладений в «Вказівках по військово-польовій хірургії», що написані під керівництвом М. Бурденка. В цьому документі вперше в історії радянської військової медицини були встановлені єдині методи і єдина тактика хірургічної медичної допомоги на етапах медичної евакуації.

Щодо евакуаційних заходів, то особливі труднощі були пов'язані 3 нестачею санітарного транспорту, особливо автомобільного. Перший санітарний автомобіль радянського виробництва надійшов у армію в 1930 р. Перший санітарний літак радянського виробництва був створений у 1927 р., але на оснащення армії санітарні літаки надійшли значно пізніше. Таким чином, до 30-х років військово-санітарна служба РСЧА фактично мала, окрім військово-санітарних поїздів, тільки один вид санітарноевакуаційного транспорту, а саме - кінно-санітарний (Організація медичного забезпечення військ, 2005: 22). До кінця 1942 р. некомплект машин в автосанітарних ротах досягав на Брянському фронті - 21,5\%, Воронезькому - 42\%. Багато автомобілів та санітарних літаків були несправні (Кувшинский, 1968: 208).

Медична служба на початку війни мала 350 літаків. До осені 1941 р. їх число зменшилось на 43\%, бо санітарні літаки літали без прикриття і були атаковані ворогом. Станом на 1 січня 1942 p. їх було тільки 202, а на грудень 1942 р. - всього лиш 243. Протягом 1942 р. незначно зросла кількість військово-санітарних поїздів з 418 до 431. Ці поїзди мали значення для евакуації поранених, були обладнані операційними вагонами, які дозволяли провести необхідні оперативні втручання вчасно, по дорозі в тилові госпіталі країни.

У 1944 р. підвищилась забезпеченість фронтів санітарним транспортом. У розпорядженні кожного фронту стало по одному окремому санітарному авіаційному полку, а в окремих фронтах, окрім цього, були ще й окремі санітарні авіаційні ескадрильї. Загальновійськові армії мали по одній автосанітарній роті, а танкові армії - автосанітарні взводи (Організація медичного забезпечення військ, 2005: 30).

У цьому ж періоді вдалось покращити стан лікувального забезпечення. До 1 грудня 1944 р. було повернено на фронт 90,4\% поранених і хворих від загальної кількості санітарних втрат, 
порівняно з 76,4\% у 1943 р. У 1944 р. летальність у лікувальних закладах знизилась порівняно з 1943 р. з 2,7\% до 1,8\% (до кількості всіх результатів лікування). Військово-медична служба перед завершенням війни в 1945 р. набула значного досвіду роботи у великих наступальних операціях стратегічного характеру. У цей час повністю оформилася прогресивна система лікувально-евакуаційного забезпечення поранених і хворих з евакуацією за призначенням. Головний внесок медичної служби ЗС СРСР в перемогу у війні - це повернення до лав 72,3\% поранених та 90,6\% хворих солдатів і офіцерів (Організачія медичного забезпечення військ, 2005: 31).

Висновки. Друга світова війна стала серйозним викликом для радянської військово-медичної служби. В ході війни поступово покращувались організація медичної допомоги, забезпечення медичними кадрами, зміцнювалась матеріально-технічна база, зростала кількість санітарного транспорту. Зокрема, враховуючи досвід війни, посаду лікаря батальйону замінили фельдшерською, більш доцільною, а лікарі працювали в полкових та дивізійних медичних пунктах. 3'являються нові лікувальні заклади, зростає ліжковий фонд госпітальних баз армій і фронтів, замість уніфікованих польових рухомих госпіталів були створені профільовані хірургічні і терапевтичні польові рухомі госпіталі, госпіталі для легкопоранених - для швидкого повернення їх у стрій. Під час війни запроваджено пересувні мобільні станції переливання крові для кожного фронту, введено централізоване постачання армії кров'ю та ії препаратами. Виходячи 3 досвіду роботи у фронтових умовах, вченими розроблений двоетапний метод заготівлі крові, котрий на сьогодні є практичною основою для консервування крові.

Оскільки на фронті бракувало медичних кадрів як лікарського, так і середнього та молодшого медичного персоналу, це спричинило збільшення кількості військово-медичних освітніх закладів, шкіл, курсів перепідготовки. Покращилась укомплектованість медичними кадрами завдяки реорганізації військово-медичної та медичної освіти. Зросла якість освіти - в ході війни повернули повноцінний термін навчання для військових медиків. Під час війни не вистачало командних кадрів медичної служби, і в 1943 р. було вирішено створити командно-медичний факультет в Військово-медичній академії ім. Кірова, що відіграло важливу роль в військово-медичній освіті. 
Досвід Другої світової війни - це потужний внесок у військово-польову хірургію. Вирішилась проблема первинної хірургічної обробки вогнепальної рани з забороною накладення на неї шва відразу після іï обробки. Заборона накладення первинного шва після первинної хірургічної обробки вогнепальної рани застосовувалась всіма хірургами Червоної армії і спиралась на військовий хірургічний досвід, викладений у «Вказівках по військовопольовій хірургії» М. Бурденка. Якщо на початку війни не були введені єдині принципи надання медичної допомоги для цивільної та військової медицини, що спричиняло розходження в лікуванні поранених, то цьому документі вперше в історії радянської військової медицини були встановлені єдині методи і єдина тактика хірургічної медичної допомоги на етапах медичної евакуації.

Від початку війни катастрофічно не вистачало медичного майна, зокрема через бомбардування та евакуацію підприємств в глиб країни. Не було санітарного транспорту - недолуга соціалістична економіка не була здатна продукувати в достатній кількості санітарні автомобілі та санітарні літаки. Тому на початку війни основний засіб санітарного транспорту був кінно-санітарний. Однак з перебудовою військової економіки та ростом машинобудування покращилося матеріально-технічне забезпечення військовомедичної служби, фронти отримали санавіаційні полки та ескадрильї, а загальновійськові армії - автосанітарні роти.

Враховуючи досвід війни, повністю оформилася система лікувально-евакуаційного забезпечення поранених і хворих з евакуацією за призначенням. Проведені лікувальні та санітарно-профілактичні заходи повернули до лав армії 72,3\% поранених і 90,6\% хворих. Військова медицина отримала неоціненний бойовий досвід, який дав могутній поштовх для подальшого розвитку воєнної науки, освіти і техніки.

\section{Використані посилання}

Военно-санитарное дело (1929). № 1. С. 104-106.

Iсторія розвитку застосування крові [online] Доступно http://hocsk.ks.ua/ statti-ta-publikatsiyi [Дата звернення 12 березня 2020].

Кувшинский Д.Д., Георгиевский А.С. (1968) Очерки истории советской военной медицинь. Издательство «Медицина», Ленинградское отделение. 520 с.

Пасько В.В (2005) Організація медичного забезпечення військ. Київ, 429 с.

Приказ РЗС СРСР, 1929 р., № 131.

Устав военно-санитарной службы РККА, Москва, 1933. 


\section{References}

Military-Sanitary Affairs (1929). No. 1. pp. 104-106.

History of blood application [online] Available from http://hocsk.ks.ua/statti-tapublikatsiyi [Last accessed 12 March 2020].

Kuvshinsky D., Georgievsky A. (1968) Essays of the History of Soviet Military Medicine. Publishing House "Medicine", Leningrad Branch, $520 \mathrm{p}$.

Pasko V. (2005) Organization of medical troops support. Kyiv, 429 p.

Order of the RZS USSR (1929) No. 131.

Charter of the military and sanitary service of the Red Army, Moscow, 1933.

\section{Kazan E., Holiachuk I.}

\section{FORMATION AND DEVELOPMENT OF RED ARMY MILITARY MEDICAL SERVICE DURING THE WORLD WAR II}

The article reflects the impact of the Second World War on the process of forming the military medical service of the USSR, of which Ukraine was a part at that time. It was shown how medical support was changed in different periods of the war, how military-medical education and science developed, approaches to providing medical assistance in combat conditions, system of medical-evacuation support was improved, material-technical base was developed, and sanitary transport and aviation, medical institutions were developed. Staffed in peacetime, they had insufficient staff, property and transportation for the war. No uniform principles for the provision of medical assistance for civil and military medicine were introduced, which led to differences in the treatment of the wounded. The experience gained by the medical service of the Soviet-Finnish war gave much value for military surgery. The problem of primary surgical treatment of a gunshot wound with the prohibition of suturing immediately after treatment was solved, and this principle was applied throughout the Second World War. It is proved that the Second World War gave a powerful impetus for the development of military medicine, its science, technology and education, increased staffing due to the reorganization of military medical and medical education. The bed fund increased, the logistics were improved, the fronts received sanitary regiments, and the armies - auto-sanitary companies, a system of medical and evacuation support with emergency evacuation was formed. Conducted medical events and measures returned to the ranks of the army $72.3 \%$ of wounded and $90.6 \%$ of patients. Military medicine has received invaluable combat experience, which has given a powerful impetus to national science, technology and education.

Keywords: health service, World War II, The Workers' and Peasants' Red Army (WPRA). 